\title{
Agrococcus terreus sp. nov. and Micrococcus terreus sp. nov., isolated from forest soil
}

Correspondence

Shuang-Jiang Liu liusj@sun.im.ac.cn
Jia-Yue Zhang, ${ }^{1}$ Xing-Yu Liu ${ }^{1,2}$ and Shuang-Jiang Liu ${ }^{1}$

\author{
${ }^{1}$ State Key Laboratory of Microbial Resources, Institute of Microbiology, Chinese Academy of \\ Sciences, Beijing 100101, PR China \\ ${ }^{2}$ National Engineering Laboratory of Biohydrometallurgy, General Research Institute for Nonferrous \\ Metals, Beijing 100088, PR China
}

Two bacterial strains, $\mathrm{DNG} 5^{\top}$ and $\mathrm{V} 3 \mathrm{M} 1^{\top}$, isolated from forest soil of the Changbai mountains in China, were characterized using a polyphasic approach. Analysis of their $16 \mathrm{~S}$ rRNA gene sequences indicated that strains $\mathrm{DNG} 5^{\top}$ and $\mathrm{V} 3 \mathrm{M} 1^{\top}$ were phylogenetically related to members of the genus Agrococcus (96.0-98.4\% similarity) and Micrococcus (96.7$98.0 \%$ similarity), respectively, within the order Actinomycetales. Strains $\mathrm{DNG} 5^{\top}$ and $\mathrm{V} 3 \mathrm{M} 1^{\top}$ were Gram-stain-positive and strictly aerobic and formed yellow colonies on LB agar. Cells of strain DNG5 ${ }^{\top}$ were short, non-motile rods, 0.4-0.5 $\times 0.8-1.0 \mu \mathrm{m}$. Strain $\mathrm{DNG} 5^{\top}$ contained MK-10 and MK-11 as the major respiratory quinones and anteiso- $\mathrm{C}_{15: 0}(49.2 \%)$ and iso$\mathrm{C}_{16: 0}(22.4 \%)$ as the major fatty acids. The diamino acid in the peptidoglycan of strain $\mathrm{DNG5}^{\mathrm{T}}$ was 2,4-diaminobutyric acid and the murein was of the acetyl type. Cells of strain $\mathrm{V} 3 \mathrm{M} 1^{\top}$ were cocci, 0.6-0.7 $\mu \mathrm{m}$ in diameter. The cell-wall peptidoglycan of strain $\mathrm{V} 3 \mathrm{M} 1^{\top}$ contained the amino acids lysine, glutamic acid, alanine and glycine. Strain $\mathrm{V} 3 \mathrm{M} 1^{\top}$ contained MK-7, MK-7 $\left(\mathrm{H}_{2}\right), \mathrm{MK}-8$ and $\mathrm{MK}-8\left(\mathrm{H}_{2}\right)$ as respiratory quinones and anteiso- $\mathrm{C}_{15: 0}(78.2 \%)$ and iso- $\mathrm{C}_{15: 0}(13.1 \%)$ as the major cellular fatty acids. The DNA $\mathrm{G}+\mathrm{C}$ contents of strains $\mathrm{DNG}^{\top}$ and $\mathrm{V} 3 \mathrm{M} 1^{\top}$ were 75.9 and $67.2 \mathrm{~mol} \%$, respectively. The DNA-DNA relatedness of

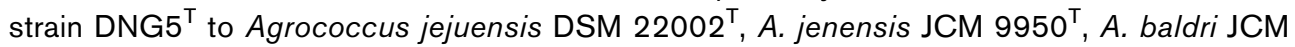
$12132^{\top}$ and $A$. citreus JCM $12398^{\top}$ was $58.3,43.9,36.1$ and $54.1 \%$, respectively. The DNADNA relatedness of strain $\mathrm{V} 3 \mathrm{M} 1^{\top}$ to Micrococcus luteus CGMCC $1.2299^{\top}$, M. antarcticus CGMCC $1.2373^{\top}$ and M. Iylae CGMCC $1.2300^{\top}$ was $57.5,45.4$ and $39.0 \%$, respectively. Combining phenotypic and genotypic traits, strain $D N G 5^{\top}$ represents a novel species of the genus Agrococcus, for which the name Agrococcus terreus sp. nov. is proposed, with $\mathrm{DNG5}^{\top}\left(=\mathrm{CGMCC} 1.6960^{\top}=\mathrm{NBRC} 104260^{\top}\right)$ as the type strain. Strain $\mathrm{V} 3 \mathrm{M}^{\top}$ represents a novel species of the genus Micrococcus, for which the name Micrococcus terreus sp. nov. is proposed, with $\mathrm{V} 3 \mathrm{M} 1^{\top}\left(=\mathrm{CGMCC} 1.7054^{\top}=\mathrm{NBRC} 104258^{\top}\right)$ as the type strain.
Within the order Actinomycetales, the genus Agrococcus is a member of the family Microbacteriaceae and the genus Micrococcus is assigned to the family Micrococcaceae. The genus Agrococcus was created by Groth et al. (1996) and, at the time of writing, includes seven species with validly published names (http://www.bacterio.cict.fr/a/agrococcus.

The GenBank/EMBL/DDBJ accession numbers for the 16S rRNA gene sequences of strains $\mathrm{DNG}^{\top}$ and $\mathrm{V} 3 \mathrm{M} 1^{\top}$ are respectively $\mathrm{FJ} 423764$ and FJ423763.

Maximum-parsimony $16 \mathrm{~S}$ rRNA gene sequence-based trees and an extended neighbour-joining tree, results of 2D TLC of polar lipids of the novel strains and detailed fatty acid profiles are available as supplementary material with the online version of this paper. html). Members of the genus Agrococcus have been isolated from various environments including soil samples (Groth et al., 1996; Wieser et al., 1999; Mayilraj et al., 2006), cheese surfaces (Bora et al., 2007), potato plants (Behrendt et al., 2008) and dried seaweed (Lee, 2008), as well as from the air (Zlamala et al., 2002). Chemotaxonomically, species of Agrococcus contain 2,4-diaminobutyric acid as the characteristic cell-wall diamino acid, phosphatidylglycerol and diphosphatidylglycerol as the major lipids (polar lipids have not been determined for Agrococcus versicolor), anteiso$\mathrm{C}_{15: 0}$ as the major fatty acid and acetyl-type murein.

The genus Micrococcus was first described by Cohn (1872). The description of this genus has been emended several 
times with reference to glucose utilization and fermentation, $\mathrm{G}+\mathrm{C}$ content of the genomic DNA and phylogenetic analysis of the 16S rRNA gene (detailed by Wieser et al., 2002). At the time of writing, the genus includes four species with validly published names, Micrococcus luteus, M. lylae (Stackebrandt et al., 1995; Kloos et al., 1974), M. antarcticus (Liu et al., 2000) and M. flavus (Liu et al., 2007). Members of this genus are yellow- or white-pigmented, non-fermentative, Gram-positive and non-motile and are characterized by the presence of anteiso- $\mathrm{C}_{15: 0}$ and iso$\mathrm{C}_{15: 0}$ as major fatty acids and MK-8 and $\mathrm{MK}-8\left(\mathrm{H}_{2}\right)$ as respiratory quinones.

In this note, we report the isolation and identification of two novel isolates, strains $\mathrm{DNG}^{\mathrm{T}}$ and $\mathrm{V} 3 \mathrm{M} 1^{\mathrm{T}}$, from a forest soil sample. In an attempt to study the microbial diversity and cultivability of forest soil of the Changbai mountains, Heilongjiang Province, China, bacterial strains were isolated by using the serial dilution method (Janssen et al., 2002). DNG medium used in this study contained $0.15 \mathrm{~g}$ Bacto tryptic soy broth and $1.5 \mathrm{~g}$ gellan in $100 \mathrm{ml}$ water. V3M medium was modified from VL55 medium (Sait et al., 2002) by addition of $5 \mathrm{ml}$ amino acid mixture (Davis et al., 2005), $1 \mathrm{ml}$ vitamin solution 1 and $3 \mathrm{ml}$ vitamin solution 2 (Janssen et al., 1997), $100 \mu \mathrm{l}$ solution 1, $3 \mathrm{ml}$ solution 2 and $3 \mathrm{ml}$ solution 3 per litre of medium, and using $1.5 \%$ gellan as solidifying agent (Davis et al., 2005). Solution 1 contained the following ingredients $\left(\mathrm{l}^{-1}\right): 4 \mathrm{mg} \mathrm{SrCl}_{2}$, $3 \mathrm{mg} \mathrm{NaSiO} 3.9 \mathrm{H}_{2} \mathrm{O}, 3 \mathrm{mg} \mathrm{TiO} 2,2 \mathrm{mg} \mathrm{Cd}\left(\mathrm{NO}_{3}\right)_{2} \cdot 4 \mathrm{H}_{2} \mathrm{O}$ and $2 \mathrm{mg} \mathrm{SnCl} 2 . \mathrm{H}_{2} \mathrm{O}$. Solution 2 contained $\left(\mathrm{l}^{-1}\right) 30 \mathrm{mg}$ DL-glyceraldehyde, $20 \mathrm{mg}$ chromotropic acid, $70 \mathrm{mg}$ gallic acid, $30 \mathrm{mg}$ ascorbic acid, $10 \mathrm{mg}$ sodium thioglycolate, $50 \mathrm{mg}$ sodium succinate, $50 \mathrm{mg}$ DL-malic acid, $50 \mathrm{mg}$ saligenin, $50 \mathrm{mg}$ sorbitol, $40 \mathrm{mg}$ salicin, $20 \mathrm{mg}$ barbital, $20 \mathrm{mg}$ aconitic acid, $30 \mathrm{mg}$ creatine and $30 \mathrm{mg}$ sodium deoxycholate. Solution 3 contained $\left(1^{-1}\right) 26 \mathrm{mg}$ L-rhamnose, $58 \mathrm{mg}$ melezitose, $38 \mathrm{mg}$ raffinose, $24 \mathrm{mg}$ galactose, $37 \mathrm{mg}$ melibiose, $64 \mathrm{mg}$ inulin, $24 \mathrm{mg}$ arabinose, $43 \mathrm{mg}$ xylose and $54 \mathrm{mg}$ cellobiose. Plates were inoculated with $10^{-5}$ to $10^{-9}$ dilutions and were sealed with Parafilm. Strains $\mathrm{DNG} 5^{\mathrm{T}}$ and $\mathrm{V} 3 \mathrm{M}^{\mathrm{T}}$ were obtained from DNG agar and $\mathrm{V} 3 \mathrm{M}$ agar plates, respectively, inoculated with the $10^{-7}$ dilution after 1 week of incubation at $25{ }^{\circ} \mathrm{C}$ and were obtained by repeated streaking.

Nearly complete $16 \mathrm{~S}$ rRNA genes of strains DNG5 ${ }^{\mathrm{T}}$ $(1516 \mathrm{bp})$ and $\mathrm{V} 3 \mathrm{M}^{\mathrm{T}}$ (1514 bp) were amplified and sequenced as described by Zhang et al. (2003). DNA BLAST searches on NCBI (Altschul et al., 1990) showed that strains $\mathrm{DNG5}^{\mathrm{T}}$ and $\mathrm{V} 3 \mathrm{Ml}^{\mathrm{T}}$ were phylogenetically related to members of the genera Agrococcus and Micrococcus, respectively. Alignments of $16 \mathrm{~S}$ rRNA gene sequences were performed with the CLUSTAL_X program (version 1.64b; Thompson et al., 1997) and alignment positions with insertions or deletions were excluded from our calculations. Phylogenetic trees based on $16 \mathrm{~S}$ rRNA gene sequence analysis were constructed by the neighbour-joining and maximumparsimony methods with Kimura's two-parameter calculation model in MEGA version 3.1 (Kumar et al., 2004).
Analysis of 16S rRNA gene sequences indicated that strain $\mathrm{DNG5}^{\mathrm{T}}$ was phylogenetically related to members of the genus Agrococcus, with similarities ranging from 96.0 to $98.4 \%$. In particular, strain $\mathrm{DNG5}^{\mathrm{T}}$ was closely related to Agrococcus jejuensis SSW1- $48^{\mathrm{T}}(98.4 \%)$, A. jenensis DSM $9580^{\mathrm{T}}(98.1 \%)$, A. baldri $\mathrm{V}-108^{\mathrm{T}}(98.1 \%)$ and A. citreus IAM $15145^{\mathrm{T}}(97.9 \%)$. The phylogenetic tree (Fig. 1a) also indicated that strain $\mathrm{DNG}^{\mathrm{T}}$ clustered with Agrococcus species; the topology of the maximum-parsimony tree was essentially the same (Supplementary Fig. S1, available in IJSEM Online).

Analysis of 16S rRNA gene sequences indicated that strain $\mathrm{V} 3 \mathrm{M}^{\mathrm{T}}$ was phylogenetically related to members of the genus Micrococcus. In particular, strain $\mathrm{V} 3 \mathrm{M} 1^{\mathrm{T}}$ was closely related to M. luteus DSM $20030^{\mathrm{T}}$ (98.0\%), M. antarcticus $\mathrm{T} 2^{\mathrm{T}}$ (97.6\%), M. lylae DSM $20315^{\mathrm{T}}(97.5 \%)$ and M. flavus LW4 ${ }^{\mathrm{T}} \quad(96.7 \%)$. Phylogenetic trees (Fig. $1 \mathrm{~b}$ and Supplementary Fig. S2) also indicated that strain $\mathrm{V} 3 \mathrm{M}^{\mathrm{T}}$ clustered with Micrococcus species, and the topology of the maximum-parsimony tree was essentially the same (Supplementary Fig. S3).

The morphological, physiological and biochemical characteristics of strains $\mathrm{DNG} 5^{\mathrm{T}}$ and $\mathrm{V} 3 \mathrm{M} 1^{\mathrm{T}}$ were investigated using routine cultivation on LB agar at $30^{\circ} \mathrm{C}$. Gram staining was performed according to Gerhardt et al. (1994) with cells grown on $\mathrm{LB}$ agar at $30{ }^{\circ} \mathrm{C}$ for 2 days. Morphological observation was performed by scanning electron microscopy (FEI Quanta 200). The presence of flagella, gliding motility and growth under anaerobic conditions were examined according to Dong \& Cai (2001). The growth temperature range was determined with a TN3F temperature-gradient incubator (Advantec) at $9,10,11,12,13,14,15.5,16,17.5,19,20,22,24,27,28,29$, $31,34,35,38,40,45,49,51,56$ and $61{ }^{\circ} \mathrm{C}$. The $\mathrm{pH}$ range for growth was tested at $\mathrm{pH} 4.0,4.8,5.5,6.0,6.5,7.0,7.5$, 8.0, 8.5, 9.0 and 9.8 in LB broth. The $\mathrm{pH}$ was adjusted by addition of $5 \mathrm{M} \mathrm{NaOH}$ or $\mathrm{HCl}$ and verified after autoclaving. Tolerance of $\mathrm{NaCl}$ was examined in $\mathrm{LB}$ broth supplemented with $0,0.25,0.5,1,2,4$ and $5 \%(\mathrm{w} / \mathrm{v}) \mathrm{NaCl}$. Tests for catalase and oxidase activities, the VogesProskauer reaction, the methyl red test and hydrolysis of casein, starch, tyrosine and Tweens 20 and 80 were carried out according to Dong \& Cai (2001). In addition, strains $\mathrm{DNG}^{\mathrm{T}}$ and $\mathrm{V} 3 \mathrm{M}^{\mathrm{T}}$ were characterized by using API 20NE, API $50 \mathrm{CH}$ and API ZYM identification systems (bioMérieux) at $30{ }^{\circ} \mathrm{C}$.

Strain DNG5 ${ }^{\mathrm{T}}$ was strictly aerobic. Cells of strain DNG5 ${ }^{\mathrm{T}}$ were Gram-stain-positive, non-motile, short rods, 0.4$0.5 \mu \mathrm{m}$ in diameter and $0.8-1.0 \mu \mathrm{m}$ long. Strain $\mathrm{V} 3 \mathrm{M}^{\mathrm{T}}$ was also strictly aerobic. Cells of strain $\mathrm{V} 3 \mathrm{M}^{\mathrm{T}}$ were nonmotile, Gram-stain-positive cocci, $0.6-0.7 \mu \mathrm{m}$ in diameter. Detailed physiological and biochemical characteristics of strains $\mathrm{DNG}^{\mathrm{T}}$ and $\mathrm{V} 3 \mathrm{Ml}^{\mathrm{T}}$ are provided in the species descriptions; differential properties from other Agrococcus and Micrococcus species, respectively, are listed in Tables 1 and 2. 
(a)

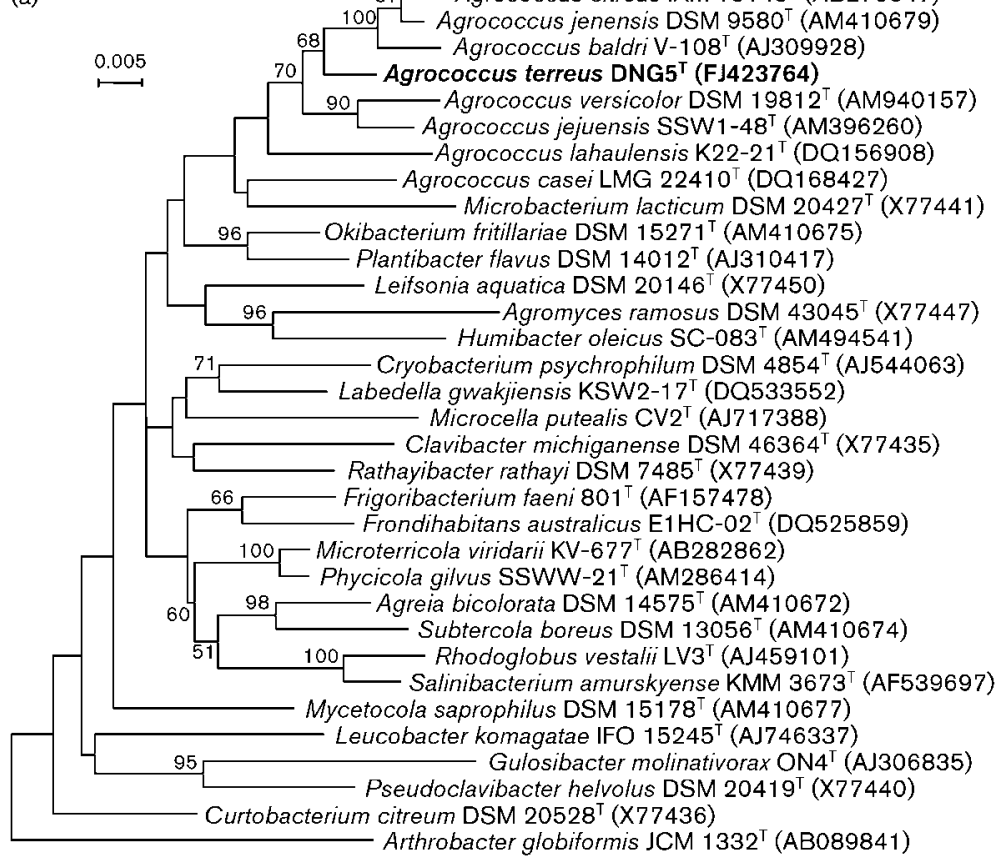

(b)

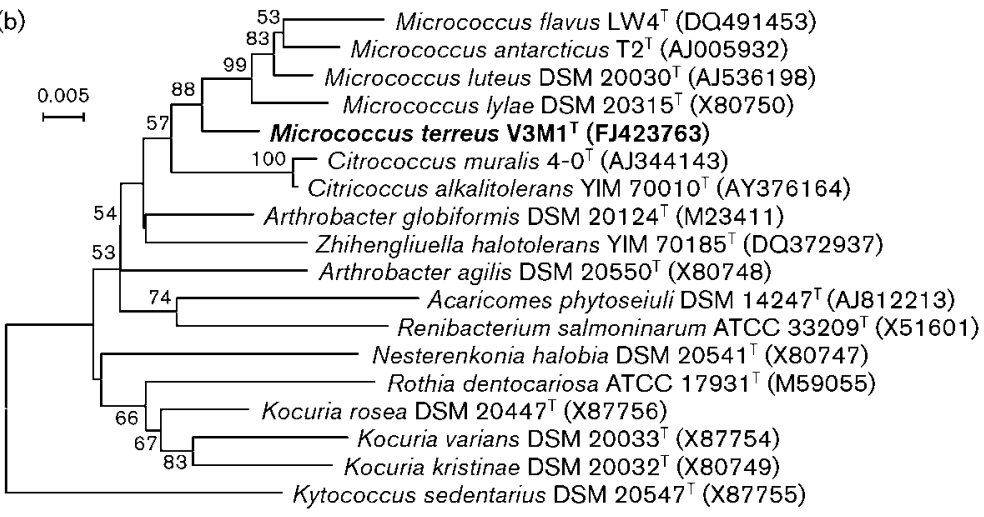

Fig. 1. Phylogenetic trees constructed with the neighbour-joining method showing (a) that strain $\mathrm{DNG} 5^{\top}$ and other members of the genus Agrococcus are clustered together and (b) that strain $\mathrm{V} 3 \mathrm{M} 1{ }^{\top}$ and other members of the genus Micrococcus are clustered together. GenBank accession numbers are given in parentheses. Numbers represent percentage confidence levels (values $>50 \%$ are shown) from bootstrap resampling with 1000 replicates. Outgroups were the sequences of Arthrobacter globiformis JCM $1332^{\top}$ (a) and Kytococcus sedentarius DSM $20547^{\top}$ (b). Bars, evolutionary distances $\left(K_{\text {nuc }}\right)$ of 0.005 .
Cell mass of strains $\mathrm{DNG}^{\mathrm{T}}$ and $\mathrm{V} 3 \mathrm{M} 1^{\mathrm{T}}$ used for chemotaxonomic analyses was produced on TSB agar and LB agar, respectively, at $30{ }^{\circ} \mathrm{C}$ for 2 days. Cellular fatty acids were extracted, methylated and analysed by using the Sherlock Microbial Identification System following the manufacturer's instructions. Polar lipids were extracted by the modified method of Kamekura (1993) and separated by TLC on Merck Kieselgel 60-HPTLC by twodimensional development as described by Ross et al. (1985). Phospholipids were detected with the Zinzadze reagent of Dittmer \& Lester (1964). Glycolipids were detected by spraying the plate with $0.5 \% 1$-naphthol in methanol/ water $(1: 1, \mathrm{v} / \mathrm{v})$ and then with sulfuric acid/ethanol $(1: 1$, $\mathrm{v} / \mathrm{v}$ ), followed by heating at $120{ }^{\circ} \mathrm{C}$ for $5-10 \mathrm{~min}$ (Xin et al., 2001). The acyl type of cellular murein of $\mathrm{DNG}^{\mathrm{T}}$ was determined as described by Uchida \& Aida (1984), with Nocardioides albus CGMCC $4.1230^{\mathrm{T}}$ as a reference strain in a parallel experiment. Isoprenoid quinones of strains $\mathrm{DNG} 5^{\mathrm{T}}$ and $\mathrm{V} 3 \mathrm{M1}^{\mathrm{T}}$, A. jenensis JCM $9950^{\mathrm{T}}$, A. baldri JCM $12132^{\mathrm{T}}$ were extracted and purified in parallel according to the method of Collins (1985) and were analysed with HPLC (Wu et al., 1989; Hu et al., 2004), with a previously characterized mixture of various menaquinones and ubiquinones. Cellwall analysis of $\mathrm{DNG}^{\mathrm{T}}$ and $\mathrm{V} 3 \mathrm{Ml}^{\mathrm{T}}$ was carried out as described by Staneck \& Roberts (1974) and Dong \& Cai (2001), with lysine, glutamic acid, alanine, glycine and aspartic acid as reference substances and A. baldri JCM $12132^{\mathrm{T}}$ as a reference strain in a parallel experiment.

The most abundant cellular fatty acids of strain $\mathrm{DNG} 5^{\mathrm{T}}$ were anteiso- $\mathrm{C}_{15: 0}(49.2 \%)$ and iso- $\mathrm{C}_{16: 0}(22.4 \%)$. The complete fatty acid profiles of strain $\mathrm{DNG} 5^{\mathrm{T}}$ and other Agrococcus species are summarized in Supplementary Table S1. The major fatty acids of strain $\mathrm{DNG} 5^{\mathrm{T}}$ was similar to those of Agrococcus species, although strain $\mathrm{DNG}^{\mathrm{T}}$ contained a significant amount $(1.8 \%)$ of anteiso- $\mathrm{C}_{15: 1}$, in contrast to other Agrococcus species. The major respiratory quinones of strain $\mathrm{DNG}^{\mathrm{T}}$ were MK-10 (39\%) and MK-11 
Table 1. Phenotypic characteristics that differentiate strain $D N G 5^{\top}$ from the type strains of other Agrococcus species

Strains: 1. A. terreus sp. nov. DNG5 ${ }^{\mathrm{T}}$; 2. A. jejuensis SSW1-48 ${ }^{\mathrm{T}} ; 3$, A. baldri $\mathrm{V}-108^{\mathrm{T}} ; 4$, A. jenensis 2002-39/1 ${ }^{\mathrm{T}} ; 5$, A. citreus $\mathrm{D}-1 / 1 \mathrm{a}^{\mathrm{T}} ; 6$, A. versicolor $\mathrm{K} 114 / 01^{\mathrm{T}}$; 7, A. lahaulensis K22-21 ${ }^{\mathrm{T}} ; 8$, A. casei R-17892t2 ${ }^{\mathrm{T}}$. Data were taken from Groth et al. (1996), Wieser et al. (1999), Zlamala et al. (2002), Mayilraj et al. (2006), Bora et al. (2007), Behrendt et al. (2008), Lee (2008) and this study. A. terreus DNG5 ${ }^{\mathrm{T}}$, A. jejuensis DSM 22002 ${ }^{\mathrm{T}}$, A. baldri JCM $12132^{\mathrm{T}}$, A. jenensis JCM $9950^{\mathrm{T}}$ and A. citreus JCM $12398^{\mathrm{T}}$ were tested in parallel with the API $20 \mathrm{NE}$ system in this study. All strains are positive for catalase activity and negative for oxidase activity, the Voges-Proskauer reaction and assimilation of citrate. + , Positive; - , negative; $(+)$, weakly positive; ND, no data available.

\begin{tabular}{|c|c|c|c|c|c|c|c|c|}
\hline Characteristic & 1 & 2 & 3 & 4 & 5 & 6 & 7 & 8 \\
\hline Cell morphology & $\begin{array}{r}\text { Short } \\
\text { rods }\end{array}$ & $\begin{array}{r}\text { Short } \\
\text { rods }\end{array}$ & $\begin{array}{l}\text { Irregular } \\
\text { coccoids } \\
\text { to rods }\end{array}$ & $\begin{array}{c}\text { Irregular } \\
\text { spherical or } \\
\text { ovoid to short rods }\end{array}$ & $\begin{array}{l}\text { Irregular } \\
\text { spherical, } \\
\text { ovoid or rods }\end{array}$ & $\begin{array}{c}\text { Short to } \\
\text { ovoid } \\
\text { rods }\end{array}$ & $\begin{array}{l}\text { Irregular } \\
\text { spherical } \\
\text { rods }\end{array}$ & $\begin{array}{l}\text { Irregular } \\
\text { ovoid to } \\
\text { short rods }\end{array}$ \\
\hline \multicolumn{9}{|l|}{ Cell size $(\mu \mathrm{m})$} \\
\hline Length & $0.8-1.0$ & $1.3-1.5$ & $1.1-1.7$ & $0.7-1.7$ & $1.1-1.7$ & $0.5-0.6$ & $1.0-1.5$ & $0.8-1.0$ \\
\hline Width & $0.4-0.5$ & $0.3-0.4$ & $0.7-1.0$ & $0.7-1.0$ & $0.7-1.0$ & $0.8-1.2$ & $0.6-1.0$ & $0.3-0.4$ \\
\hline Colony colour & Yellow & Yellow & Light yellow & White or orange & Yellow & $\begin{array}{l}\text { Yellow to } \\
\text { dark pink }\end{array}$ & Lemon & Cream \\
\hline $\begin{array}{l}\text { Optimum growth } \\
\text { temperature }\left({ }^{\circ} \mathrm{C}\right)\end{array}$ & 30 & 30 & 28 & 28 & 28 & 21 & 30 & 30 \\
\hline \multicolumn{9}{|l|}{ Hydrolysis of: } \\
\hline Starch & - & - & + & + & + & - & + & + \\
\hline Casein & - & + & - & - & - & + & + & - \\
\hline Tween 80 & - & - & + & - & + & - & - & + \\
\hline Tyrosine & - & - & - & + & + & - & - & - \\
\hline Gelatin & + & + & - & - & - & + & + & $\mathrm{ND}$ \\
\hline Aesculin & + & + & + & + & + & + & - & - \\
\hline Nitrate reduction & - & - & - & - & - & $\mathrm{ND}$ & - & ND \\
\hline \multicolumn{9}{|l|}{ Assimilation of: } \\
\hline D-Glucose & - & + & + & + & - & + & - & ND \\
\hline L-Arabinose & + & - & + & + & + & + & + & - \\
\hline D-Mannose & - & + & + & + & + & + & - & $\mathrm{ND}$ \\
\hline $\begin{array}{l}N \text {-Acetyl-D- } \\
\text { glucosamine }\end{array}$ & - & + & + & - & - & + & - & - \\
\hline Gluconate & + & - & + & + & + & + & - & - \\
\hline \multicolumn{9}{|l|}{ Acid produced from: } \\
\hline D-Glucose & + & + & + & - & + & $(+)$ & ND & + \\
\hline D-Fructose & + & + & - & + & + & $(+)$ & + & - \\
\hline D-Mannose & + & + & - & - & - & $(+)$ & $\mathrm{ND}$ & + \\
\hline Mannitol & + & - & + & + & + & - & - & - \\
\hline Cellobiose & + & + & + & + & + & - & - & - \\
\hline Maltose & $(+)$ & + & + & - & + & - & - & - \\
\hline Sucrose & + & + & + & - & - & $(+)$ & - & - \\
\hline Trehalose & + & + & + & - & + & - & + & - \\
\hline Major menaquinones & $10,11,9$ & 10,9 & 12,11 & 12,11 & 12,11 & 10,11 & $10,11,12$ & 11,12 \\
\hline $\begin{array}{l}\text { DNA G + C content } \\
(\mathrm{mol} \%)\end{array}$ & 75.9 & 73 & $73.8-74.9$ & 74 & 74 & ND & 74.1 & 65 \\
\hline
\end{tabular}

(53\%), with MK-9 (8\%) as a minor component. The diamino acid in the peptidoglycan was 2,4-diaminobutyric acid; alanine, glycine, glutamic acid and aspartic acid were also detected. The murein was of the acetyl type, and the major lipids were phosphatidylglycerol, diphosphatidylglycerol and two unknown glycolipids (Supplementary Fig. S4), which are typical characteristics of the genus Agrococcus.

The most abundant cellular fatty acids of strain $\mathrm{V} 3 \mathrm{M}^{\mathrm{T}}$ were anteiso- $\mathrm{C}_{15: 0}(78.2 \%)$ and iso- $\mathrm{C}_{15: 0}(13.1 \%)$. This fatty acid profile was similar to those of Micrococcus species, and the detailed fatty acid compositions of strain $\mathrm{V} 3 \mathrm{M} 1^{\mathrm{T}}$ and the other Micrococcus species are given in Supplementary Table S2. The major polar lipids were diphosphatidylglycerol, phosphatidylglycerol, phosphatidylinositol and an unidentified phospholipid that showed similar migration behaviour to phosphatidylcholine during TLC. Three unknown glycolipids were also detected (Supplementary Fig. S5). This polar lipid pattern was similar to those of M. lylae DSM $20315^{\mathrm{T}}$ and M. luteus 
Table 2. Phenotypic characteristics that differentiate strain $\mathrm{V} 3 \mathrm{M} 1^{\top}$ from the type strains of other Micrococcus species

Strains: 1 , M. terreus sp. nov. V3M1 ${ }^{\mathrm{T}}$; 2, M. luteus CGMCC $1.2299^{\mathrm{T}}$; 3, M. antarcticus CGMCC $1.2373^{\mathrm{T}}$; 4, M. lylae CGMCC $1.2300^{\mathrm{T}}$; 5 , M. flavus CGMCC $1.5361^{\mathrm{T}}$. All five strains were tested in parallel in this study for oxidase and catalase activities, casein hydrolysis and reactions in API $20 \mathrm{NE}$ and API ZYM tests. Other data were taken from Liu et al. (2000, 2007) and Wieser et al. (2002). +, Positive; -, negative; (+), weakly positive. All strains are positive for assimilation of maltose and malate and activities of catalase, leucine arylamidase, trypsin, $\alpha$-glucosidase and valine arylamidase. All strains are negative for motility, nitrate reduction, indole production, hydrolysis of casein and aesculin, glucose fermentation, assimilation of D-mannitol, $N$-acetyl-D-glucosamine and caprate and activities of arginine dihydrolase, esterase $\left(\mathrm{C}_{4}\right)$, esterase lipase $\left(\mathrm{C}_{8}\right)$, lipase $\left(\mathrm{C}_{14}\right), \alpha$-galactosidase, $N$-acetyl- $\beta$-glucosaminidase, $\beta$-galactosidase, $\beta$-glucuronidase, $\beta$-glucosidase and $\alpha$-fucosidase.

\begin{tabular}{|c|c|c|c|c|c|}
\hline Characteristic & 1 & 2 & 3 & 4 & 5 \\
\hline Colony colour & Yellow & Yellow & Yellow & White & Yellow \\
\hline Optimum growth temperature $\left({ }^{\circ} \mathrm{C}\right)$ & 33 & 37 & 16.8 & 37 & 31 \\
\hline Voges-Proskauer reaction & - & - & + & - & - \\
\hline Methyl red test & - & + & + & - & - \\
\hline \multicolumn{6}{|l|}{ Hydrolysis of: } \\
\hline Tween 20 & + & - & + & - & - \\
\hline Tween 80 & + & + & + & - & - \\
\hline \multicolumn{6}{|l|}{ Biochemical characteristics (API $20 \mathrm{NE}$ ) } \\
\hline Urease activity & - & + & - & + & - \\
\hline Gelatin hydrolysis & + & - & - & - & - \\
\hline \multicolumn{6}{|l|}{ Assimilation of (API 20NE): } \\
\hline Adipate & + & - & - & - & - \\
\hline Citrate & + & - & + & + & - \\
\hline Phenylacetate & + & + & + & + & - \\
\hline \multicolumn{6}{|l|}{ Enzyme activities (API ZYM) } \\
\hline Alkaline phosphatase & - & - & - & + & - \\
\hline Valine arylamidase & $(+)$ & $(+)$ & + & $(+)$ & $(+)$ \\
\hline Cystine arylamidase & - & - & + & $(+)$ & - \\
\hline$\alpha$-Chymotrypsin & $(+)$ & - & - & - & - \\
\hline Acid phosphatase & - & - & $(+)$ & - & - \\
\hline Naphthol-AS-BI-phosphohydrolase & $(+)$ & $(+)$ & $(+)$ & - & + \\
\hline$\alpha$-Mannosidase & - & - & + & - & - \\
\hline
\end{tabular}

DSM $20030^{\mathrm{T}}$ (Stackebrandt et al., 1995; Wieser et al., 2002). The predominant isoprenoid quinones were MK-7 (57.8\%), MK-7 $\left(\mathrm{H}_{2}\right)$ (21.8\%), MK-8 (15.0\%) and MK$8\left(\mathrm{H}_{2}\right)(5.4 \%)$. The cell-wall peptidoglycan of strain $\mathrm{V} 3 \mathrm{Ml}^{\mathrm{T}}$ contained the amino acids lysine, glutamic acid, alanine and glycine. These data were compatible with the typical characteristics of the genus Micrococcus.

The DNA base composition was determined by thermal denaturation (Marmur \& Doty, 1962) and Escherichia coli $\mathrm{K}-12$ was used as a reference. The DNA G $+\mathrm{C}$ content of strain DNG5 ${ }^{\mathrm{T}}$ was $75.9 \mathrm{~mol} \%$, which is close to but slightly higher than the range of values $(65-74.9 \mathrm{~mol} \%)$ reported for Agrococcus species. The DNA G $+\mathrm{C}$ content of strain $\mathrm{V} 3 \mathrm{M}^{\mathrm{T}}$ was $67.2 \mathrm{~mol} \%$, which is within the range of values (66.4-71.5 mol\%) reported for Micrococcus species.
Based on the above phenotypic and phylogenetic studies, it is clear that strains $\mathrm{DNG5}^{\mathrm{T}}$ and $\mathrm{V} 3 \mathrm{M}^{\mathrm{T}}$ are respectively members of the genera Micrococcus and Agrococcus. Strain $\mathrm{DNG}^{\mathrm{T}}$ showed a range of phenotypic characteristics that differentiated it from currently described Agrococcus species (Table 1), such as assimilation of various carbon sources, cellular fatty acids and respiratory quinones. To distinguish strain DNG5 ${ }^{\mathrm{T}}$ further from the phylogenetically highly related Agrococcus species, DNA-DNA hybridization was performed by the thermal denaturation and renaturation method of De Ley et al. (1970) as modified by Huß et al. (1983). Results showed that the DNA-DNA relatedness of strain $\mathrm{DNG5}^{\mathrm{T}}$ to A. jejuensis DSM $22002^{\mathrm{T}}$, A. jenensis JCM $9950^{\mathrm{T}}$, A. baldri JCM $12132^{\mathrm{T}}$ and A. citreus JCM $12398^{\mathrm{T}}$ was $58.3,43.9,36.1$ and $54.1 \%$, respectively. Therefore, it is concluded that bacterial strain $\mathrm{DNG5}^{\mathrm{T}}$ 
represents a novel species of the genus Agrococcus, for which the name Agrococcus terreus sp. nov. is proposed.

Strain $\mathrm{V} 3 \mathrm{M} 1^{\mathrm{T}}$ showed a range of phenotypic characteristics that differentiated it from Micrococcus species with validly published names (Table 2), such as oxidase activity, major respiratory quinones, assimilation of various carbon sources and production of different enzymes. To distinguish strain V3M1 ${ }^{\mathrm{T}}$ further from other Micrococcus species, the DNA-DNA relatedness of strain $\mathrm{V} 3 \mathrm{M}^{\mathrm{T}}$ to $M$. luteus CGMCC $1.2299^{\mathrm{T}}$, M. antarcticus CGMCC $1.2373^{\mathrm{T}}$ and $M$. lylae CGMCC $1.2300^{\mathrm{T}}$ was $57.5,45.4$ and $39.0 \%$, respectively. Therefore, it is concluded that bacterial strain $\mathrm{V} 3 \mathrm{M} 1^{\mathrm{T}}$ represents a novel species of the genus Micrococcus, for which the name Micrococcus terreus sp. nov. is proposed.

\section{Description of Agrococcus terreus sp. nov.}

Agrococcus terreus (ter're.us. L. masc. adj. terreus of the earth).

Strictly aerobic, Gram-stain-positive, heterotrophic, oxidase-negative and catalase-positive. Colonies on LB agar are circular, entire and yellow. Growth occurs at $20-40{ }^{\circ} \mathrm{C}$ (optimum, $30{ }^{\circ} \mathrm{C}$ ), at pH 5.5-9.0 (optimum, pH 7.0) and in the presence of $0-4 \% \mathrm{NaCl}$ (optimum, $1.0 \%$ ). Nitrate is not reduced. Gelatin and aesculin are hydrolysed, but tyrosine, casein, starch and Tweens 20 and 80 are not. Urease and arginine dihydrolase activities are absent. Indole is not produced. The Voges-Proskauer reaction and methyl red test are negative. Assimilates L-arabinose, D-mannose, D-mannitol, gluconate and malate, but not Dglucose, maltose, $\mathrm{N}$-acetyl-D-glucosamine, caprate, adipate, citrate or phenylacetate. In API $50 \mathrm{CH}$ tests, acids are produced from glycerol, ribose, D-glucose, D-fructose, Dmannose, rhamnose, mannitol, aesculin, cellobiose, sucrose, trehalose and turanose and are produced weakly from salicin and maltose; all other API $50 \mathrm{CH}$ tests are negative. Esterase lipase $\left(\mathrm{C}_{8}\right)$, leucine arylamidase, valine arylamidase, acid phosphatase, naphthol-AS-BI-phosphohydrolase and $\alpha$-glucosidase activities are present. Weak cystine arylamidase activity is present. Alkaline phosphatase, esterase $\left(\mathrm{C}_{4}\right)$, lipase $\left(\mathrm{C}_{14}\right)$, trypsin, $\alpha$-chymotrypsin, $\alpha$ galactosidase, $\beta$-galactosidase, $\beta$-glucuronidase, $N$-acetyl$\beta$-glucosaminidase, $\beta$-glucosidase, $\alpha$-mannosidase and $\alpha$ fucosidase activities are absent. The most abundant cellular fatty acids are anteiso- $\mathrm{C}_{15: 0}$ and iso- $\mathrm{C}_{16: 0}$. The diamino acid in the peptidoglycan is 2,4-diaminobutyric acid; alanine, glycine, glutamic acid and aspartic acid are also present. The major respiratory quinones are MK-10 and MK-11, with MK-9 as a minor component. The murein is of the acetyl type, and the major lipids are phosphatidylglycerol, diphosphatidylglycerol and two unknown glycolipids. The DNA G+C content of the type strain is $75.9 \mathrm{~mol} \%\left(T_{\mathrm{m}}\right)$.

The type strain is $\mathrm{DNG5}^{\mathrm{T}}$ (=CGMCC $1.6960^{\mathrm{T}}=\mathrm{NBRC}$ $104260^{\mathrm{T}}$ ), isolated from forest soil.

\section{Description of Micrococcus terreus sp. nov.}

Micrococcus terreus (ter're.us. L. masc. adj. terreus of the earth).

Strictly aerobic, Gram-stain-positive, heterotrophic, oxidase-negative and catalase-positive. Colonies on LB agar are circular, entire, smooth, yellow and $0.5-10 \mathrm{~mm}$ in diameter. Growth occurs at $20-35{ }^{\circ} \mathrm{C}$ (optimum, $33{ }^{\circ} \mathrm{C}$ ), at $\mathrm{pH}$ 5.0-9.0 (optimum, $\mathrm{pH} 7.0$ ) and in the presence of 0 $2 \% \mathrm{NaCl}$ (optimum, 1.0\%). Nitrate is not reduced. Gelatin and Tweens 20 and 80 are hydrolysed, but casein, starch and aesculin are not. Urease and arginine dihydrolase activities are absent. Indole is not produced. The Voges-Proskauer reaction and methyl red test are negative. D-Glucose, maltose, adipate, malate, citrate and phenylacetate are assimilated and gluconate is assimilated weakly. L-Arabinose, D-mannose, D-mannitol, $\mathrm{N}$-acetyl-D-glucosamine and caprate are not assimilated. In API $50 \mathrm{CH}$ tests, acids are produced from maltose, sucrose, trehalose and turanose; all other API $50 \mathrm{CH}$ tests are negative. Leucine arylamidase, trypsin and $\alpha$-glucosidase activities are present. Weak valine arylamidase, $\alpha$-chymotrypsin and naphthol-AS-BI-phosphohydrolase activities are present. Alkaline phosphatase, esterase $\left(\mathrm{C}_{4}\right)$, esterase lipase $\left(\mathrm{C}_{8}\right)$, lipase $\left(\mathrm{C}_{14}\right)$, cystine arylamidase, acid phosphatase, $\alpha$ galactosidase, $\beta$-galactosidase, $\beta$-glucuronidase, $\beta$-glucosidase, $N$-acetyl- $\beta$-glucosaminidase, $\alpha$-mannosidase and $\alpha$ fucosidase activities are absent. Cell-wall peptidoglycan contains the amino acids lysine, glutamic acid, alanine and glycine. The most abundant cellular fatty acids are anteiso$\mathrm{C}_{15: 0}$ and iso- $\mathrm{C}_{15: 0}$. MK-7, MK-7 $\left(\mathrm{H}_{2}\right), \mathrm{MK}-8$ and MK$8\left(\mathrm{H}_{2}\right)$ are the major respiratory quinones. The DNA G+C content of the type strain is $67.2 \mathrm{~mol} \%\left(T_{\mathrm{m}}\right)$.

The type strain is $\mathrm{V}^{2} \mathrm{M}^{\mathrm{T}}$ (=CGMCC $1.7054^{\mathrm{T}}=\mathrm{NBRC}$ $104258^{\mathrm{T}}$ ), isolated from forest soil.

\section{Acknowledgements}

This work was supported by grants from the National Nature Science Foundation of China (30725001) and the Chinese Academy of Sciences (KSCX2-YW-G-052).

\section{References}

Altschul, S. F., Gish, W., Miller, W., Myers, E. W. \& Lipman, D. J. (1990). Basic local alignment search tool. J Mol Biol 215, 403-410.

Behrendt, U., Schumann, P. \& Ulrich, A. (2008). Agrococcus versicolor sp. nov., an actinobacterium associated with the phyllosphere of potato plants. Int J Syst Evol Microbiol 58, 2833-2838.

Bora, N., Vancanneyt, M., Gelsomino, R., Swings, J., Brennan, N., Cogan, T. M., Larpin, S., Desmasures, N., Lechner, F. E. \& other authors (2007). Agrococcus casei sp. nov., isolated from the surfaces of smear-ripened cheeses. Int J Syst Evol Microbiol 57, 92-97.

Cohn, F. (1872). Untersuchungen über Bakterien. Beitr Biol Pflanz 1, 127-244 (in German).

Collins, M. D. (1985). Isoprenoid quinone analysis in classification and identification. In Chemical Methods in Bacterial Systematics, pp. 
267-287. Edited by M. Goodfellow \& D. E. Minnikin. London: Academic Press.

Davis, K. E., Joseph, S. J. \& Janssen, P. H. (2005). Effects of growth medium, inoculum size, and incubation time on culturability and isolation of soil bacteria. Appl Environ Microbiol 71, 826-834.

De Ley, J., Cattoir, H. \& Reynaerts, A. (1970). The quantitative measurement of DNA hybridization from renaturation rates. Eur Biochem 12, 133-142.

Dittmer, J. C. \& Lester, R. L. (1964). A simple, specific spray for the detection of phospholipids on thin-layer chromatograms. J Lipid Res $15,126-127$.

Dong, X.-Z. \& Cai, M.-Y. (2001). Determinative Manual for Routine Bacteriology. Beijing: Scientific Press (English translation).

Gerhardt, P., Murray, R. G. E., Wood, W. A. \& Krieg, N. R. (editors) (1994). Methods for General and Molecular Bacteriology. Washington, DC: American Society for Microbiology.

Groth, I., Schumann, P., Weiss, N., Martin, K. \& Rainey, F. A. (1996). Agrococcus jenensis gen. nov., sp. nov., a new genus of actinomycetes with diaminobutyric acid in the cell wall. Int J Syst Bacteriol 46, 234239.

Hu, H. Y., Lim, B. R., Goto, N. \& Fujie, K. (2001). Analytical precision and repeatability of respiratory quinones for quantitative study of microbial community structure in environmental samples. J Microbiol Methods 47, 17-24.

Hu, Y.-T., Zhou, P.-J., Zhou, Y.-G., Liu, Z.-H. \& Liu, S.-J. (2004). Saccharothrix xingjiangensis, sp. nov., a pyrene-degrading actinomycete isolated from Tianchi Lake, Xinjiang, China. Int J Syst Evol Microbiol 54, 2091-2094.

Huß, V. A. R., Festl, H. \& Schleifer, K. H. (1983). Studies on the spectrophotometric determination of DNA hybridization from renaturation rates. Syst Appl Microbiol 4, 184-192.

Janssen, P. H., Schuhmann, A., Morschel, E. \& Rainey, F. A. (1997). Novel anaerobic ultramicrobacteria belonging to the Verrucomicrobiales lineage of bacterial descent isolated by dilution culture from anoxic rice paddy soil. Appl Environ Microbiol 63, 13821388.

Janssen, P. H., Yates, P. S., Grinton, B. E., Taylor, P. M. \& Sait, M. (2002). Improved culturability of soil bacteria and isolation in pure culture of novel members of the divisions Acidobacteria, Actinobacteria, Proteobacteria, and Verrucomicrobia. Appl Environ Microbiol 68, 2391-2396.

Kamekura, M. (1993). Lipids of extreme halophiles. In The Biology of Halophilic Bacteria, pp. 135-161. Edited by R. H. Vreeland \& L. I. Hochstein. Boca Raton, FL: CRC Press.

Kloos, W. E., Tornabene, T. G. \& Schleifer, K. H. (1974). Isolation and characterization of micrococci from human skin, including two new species: Micrococcus lylae and Micrococcus kristinae. Int J Syst Bacteriol 24, 79-101.

Kumar, S., Tamura, K. \& Nei, M. (2004). MEGA 3: integrated software for molecular evolutionary genetics analysis and sequence alignment. Brief Bioinform 5, 150-163.

Lee, S. D. (2008). Agrococcus jejuensis sp. nov., isolated from dried seaweed. Int J Syst Evol Microbiol 58, 2297-2300.

Liu, H., Xu, Y., Ma, Y. \& Zhou, P. (2000). Characterization of Micrococcus antarcticus sp. nov., a psychrophilic bacterium from Antarctica. Int J Syst Evol Microbiol 50, 715-719.
Liu, X. Y., Wang, B. J., Jiang, C. Y. \& Liu, S. J. (2007). Micrococcus flavus sp. nov., isolated from activated sludge in a bioreactor. Int J Syst Evol Microbiol 57, 66-69.

Marmur, J. \& Doty, P. (1962). Determination of the base composition of deoxyribonucleic acid from thermal denaturation temperature. J Mol Biol 5, 109-118.

Mayilraj, S., Suresh, K., Schumann, P., Kroppenstedt, R. M. \& Saini, H. S. (2006). Agrococcus lahaulensis sp. nov., isolated from a cold desert of the Indian Himalayas. Int J Syst Evol Microbiol 56, 18071810.

Ross, H. N. M., Grant, W. D. \& Harris, J. E. (1985). Lipids in archaebacterial taxonomy. In Chemical Methods in Bacterial Systematics, pp. 289-300. Edited by M. Goodfellow \& D. E. Minnikin. London: Academic Press.

Sait, M., Hugenholtz, P. \& Janssen, P. H. (2002). Cultivation of globally distributed soil bacteria from phylogenetic lineages previously only detected in cultivation-independent surveys. Environ Microbiol 4, 654-666.

Stackebrandt, E., Koch, C., Gvozdiak, O. \& Schumann, P. (1995). Taxonomic dissection of the genus Micrococcus: Kocuria gen. nov., Nesterenkonia gen. nov., Kytococcus gen. nov., Dermacoccus gen. nov., and Micrococcus Cohn 1872 gen. emend. Int J Syst Bacteriol 45, 682692.

Staneck, J. L. \& Roberts, G. D. (1974). Simplified approach to identification of aerobic actinomycetes by thin-layer chromatography. Appl Microbiol 28, 226-231.

Thompson, J. D., Gibson, T. J., Plewniak, F., Jeanmougin, F. \& Higgins, D. G. (1997). The CLUSTAL_X windows interface: flexible strategies for multiple sequence alignment aided by quality analysis tools. Nucleic Acids Res 25, 4876-4882.

Uchida, K. \& Aida, K. (1984). An improved method for the glycolate test for simple identification of acyl type of bacterial cell walls. J Gen Appl Microbiol 30, 131-134.

Wieser, M., Schumann, P., Martin, K., Altenburger, P., Burghardt, J., Lubitz, W. \& Busse, H.-J. (1999). Agrococcus citreus sp. nov., isolated from a medieval wall painting of the chapel of Castle Herberstein (Austria). Int J Syst Bacteriol 49, 1165-1170.

Wieser, M., Denner, E. B. M., Kämpfer, P., Schumann, P., Tindall, B., Steiner, U., Vybiral, D., Lubitz, W., Maszenan, A. M. \& other authors (2002). Emended descriptions of the genus Micrococcus, Micrococcus luteus (Cohn 1872) and Micrococcus lylae (Kloos et al. 1974). Int J Syst Evol Microbiol 52, 629-637.

Wu, C., Lu, X., Qin, M., Wang, Y. \& Ruan, J. (1989). Analysis of menaquinone compound in microbial cells by HPLC. Microbiology [English translation of Microbiology (Beijing)] 16, 176-178.

Xin, H., Itoh, T., Zhou, P., Suzuki, K. \& Nakase, T. (2001). Natronobacterium nitratireducens sp. nov., a haloalkaliphilic archaeon isolated from a soda lake in China. Int J Syst Evol Microbiol 51, 18251829.

Zhang, D., Yang, H., Zhang, W., Huang, Z. \& Liu, S.-J. (2003). Rhodocista pekingensis sp. nov., a cyst-forming phototrophic bacterium from a municipal wastewater treatment plant. Int J Syst Evol Microbiol 53, 1111-1114.

Zlamala, C., Schumann, P., Kämpfer, P., Rosselló-Mora, R., Lubitz, W. \& Busse, H.-J. (2002). Agrococcus baldri sp. nov., isolated from the air in the 'Virgilkapelle' in Vienna. Int J Syst Evol Microbiol 52, 12111216. 